$\xi=$

\title{
Grazing intensity contributes to cyanogenic toxicity in savannah grasses in Baringo county
}

\author{
Alfayo, $\mathrm{K}^{1 *}$, Maranga $\mathrm{E} . \mathrm{K}^{1}$, Obonyo $\mathrm{M}^{2}$ \\ ${ }^{1}$ Egerton University, Department of Natural Resources, P.O Box 536-20115, Egerton \\ ${ }^{2}$ Egerton University, Department of Biochemistry, P.O Box 536-20115, Egerton \\ *Corresponding author E-mail: kkalfayo@gmail.com
}

\begin{abstract}
The potential role of anti-herbivory mechanisms used by plants and their synergistic responses to grazing and interactive effects on herbivores are poorly understood. The aim of this study was to quantify the influence of grazing intensity on cyanogenic glycosides in Lake Bogoria, Baringo County Kenya. Field experiments were carried out in ten $50 \times 10 \mathrm{~m}$ enclosures. Grazing intensity was varied using simulated grazing method where two grazing treatments used; heavy grazing and light grazing. Grasses were categorized into two age classes; young and old. Cyanigenic glycocides $(\mathrm{CNglc})$ were tested using impregnated picrate paper and their concentration determined by hydrolysis and trapping in $1 \mathrm{M} \mathrm{NaOH}$. Our findings showed that five of 16 sampled species produce cyanogenic glycosides; Cynodon dactylon, Cynodon plectostachyus, Digitaria scalarum, Sporobolus spicatus and Cyperus laevigatus. There was an inverse relation between Cyanide concentration and age of the plants. Young cuttings yield more Hydrogen Cyanide than older cuttings of the same grasses.Grazing intensity had a significant effect on the concentration of cyanogenic content in some grass species; $\mathrm{C}$. dactylon $(\mathrm{P}=0.024)$ and $\mathrm{S}$. laevigatus $(\mathrm{P}=0.003)$. The findings imply that grazing regime of managed pastures should consider the age of forage while allowing utilization of pastures preferably grazed on mature pastures with low levels of cyanogenic glycosides.
\end{abstract}

Keywords: Cyanogenic; Glycosides Grasses; Grazing and Intensity.

\section{Introduction}

Cyanogenic glycosides (CNglcs) are bioactive plant products derived from amino acids. They are a group of plant secondary compounds that contain nitrogen and yield cyanide (cyanogenesis) following their enzymatic breakdown (Møller 2010, p239). Natural sources of cyanide include bacteria, plants, and fungi which synthesize and secrete cyanide but the most common sources of cyanide in the environment are from industrial wastes which enter the soil through the solution with rain water and infiltration (Woodrow et al. 2002, p105).

Cyanogenesis - the release of toxic hydrogen cyanide from endogenous $\mathrm{CNglcs}$ - is an effective defense against generalist herbivores but less effective against fungal pathogens (Zagrobelny et al. 2008, p1459). Plants have evolved a plethora of different defense chemicals that covers almost all classes of (secondary) metabolites that represent a major defense to herbivory: Some are constitutive; others are induced after attack (Mithöfer \& Boland 2012, p335). According to Ballhorn et al. (2010, p250) many compounds act directly on the herbivore, whereas others act indirectly via the attraction of organisms from other trophic levels that, in turn, protect the plant. An enormous diversity of plant (bio) chemicals is toxic, repellent, or anti-nutritive for herbivores of all types. Examples include cyanogenic glycosides, glucosinolates, alkaloids, and terpenoids; others are macromolecules and comprise latex or proteinase inhibitors. Grasses are also known to produce an array of secondary metabolites, such as hydroxamic acids (Pentzold et al. 2014, p915) and alkaloids, albeit at levels much lower than dicotyledons (Zagrobelny et al. 2008, p1460). Their modes of action include membrane disruption, inhi- bition of nutrient and ion transport, inhibition of signal transduction processes, inhibition of metabolism, or disruption of the hormonal control of physiological processes.

The level of cyanogenic glycosides produced is dependent on the age and variety of the plant, as well as environmental factors (Møller 2010, p240, Ubalua 2010, p226). Production of Cyanide is thought to be due to the presence of cyanogenic glycosides that release HCN (hydrogen cyanide) when acted upon by enzymes found within plant cells (Ramirez \& Barry 2005, p181). Certain plant species synthesize cyanogenic glycosides and cyanolipids which when disrupted by grazing are hydrolyzed and in the process liberate Hydrogen Cyanide ( $\mathrm{HCN}$ ) Hydrogen cyanide that is produced by cyanogenic glycoside which potential to cause health concerns which include the arrest of the ATP production and cell death by blocking cytochrome oxidase (Sirikantaramas et al. 2008, p469). Recognizing the herbivore challenge and precise timing of plant activities as well as the adaptive modulation of the plants' metabolism is important so that metabolites and energy may be efficiently allocated to defensive activities. This study seeks to identify savanna the grasses which synthesize cyanide and attempt to elucidate the biological pathways that link mammalian grazing disturbance with cyanogen toxicity associated with these grasses in Kenya. This study also sought to explain on the concentration of cyanogenic glycosides as affected by the age of grasses.

\section{Materials and methods}

The study was conducted in fenced enclosures in Lake Bogoria $\left(00^{\circ} 20^{\prime} \mathrm{N}, 35^{\circ} 59^{\prime} \mathrm{E}\right)$ during the months of June-September; 2015.The enclosures (10 in totals each $50 \mathrm{~m} \times 10 \mathrm{~m}$ ) were estab- 
lished in June 2015 and enclosed for one month. In the first experiment, however, grasses were sampled outside enclosures on a random basis and tested for cyanogenic glycosides using picrateimpregnated paper. After identifying the grasses with cyanogenic content, enclosures in sampling points were made to determine the influence of age and grazing intensity on cyanogenic concentration. In total, the experiment consisted of 10 replicates of each of the following factorial treatments: Light grazing (LG + Plot1, p2, $\mathrm{p} 3)$, heavy grazing $(\mathrm{Hg})$, and no grazing $(\mathrm{Ng})$ in each plot. Two levels of grazing intensity were applied; light $(15 \mathrm{~cm}$ height $)$ and heavy $(5 \mathrm{~cm})$. The grazing treatment was begun in late June 2015 by first clipping then second clipping. One control experiment in each sample was established (where no consideration to variation in grazing intensity was established). Sampling units defined by quadrat measuring $0.25 \mathrm{~m}$ radius was distributed on purposive sampling. Age of grasses was classified into two; young and old pastures using characteristics such as; fluorescence, and leaf blade length. The concentration of Cyanogenic glycosides in grass extracts was measured by hydrolyzing the glycosides and trapping the evolved cyanide in $1 \mathrm{M} \mathrm{NaOH}$ well a modification of method by Gleadow et al. (1998) and Brinker and Seigler (1989). Freezedried grounded grass tissues $(10-15 \mathrm{~g})$ was incubated $20 \mathrm{~h}$ at temperature of $37^{\circ} \mathrm{c}$ with $1 \mathrm{ml}$ of $0.1 \mathrm{M}$ citrate buffer-HCL pH 5.5 , condition which allowed for complete conversion of cyanogenic glycosides to cyanide. The cyanide detected using this method is directly proportional to the concentration of cyanogenic glycosides for example; $1 \mathrm{mg} \mathrm{CN}$ is equivalent to $11.35 \mathrm{mg}$ glycoside prunasin (Gleadow and Woodrow 2002).

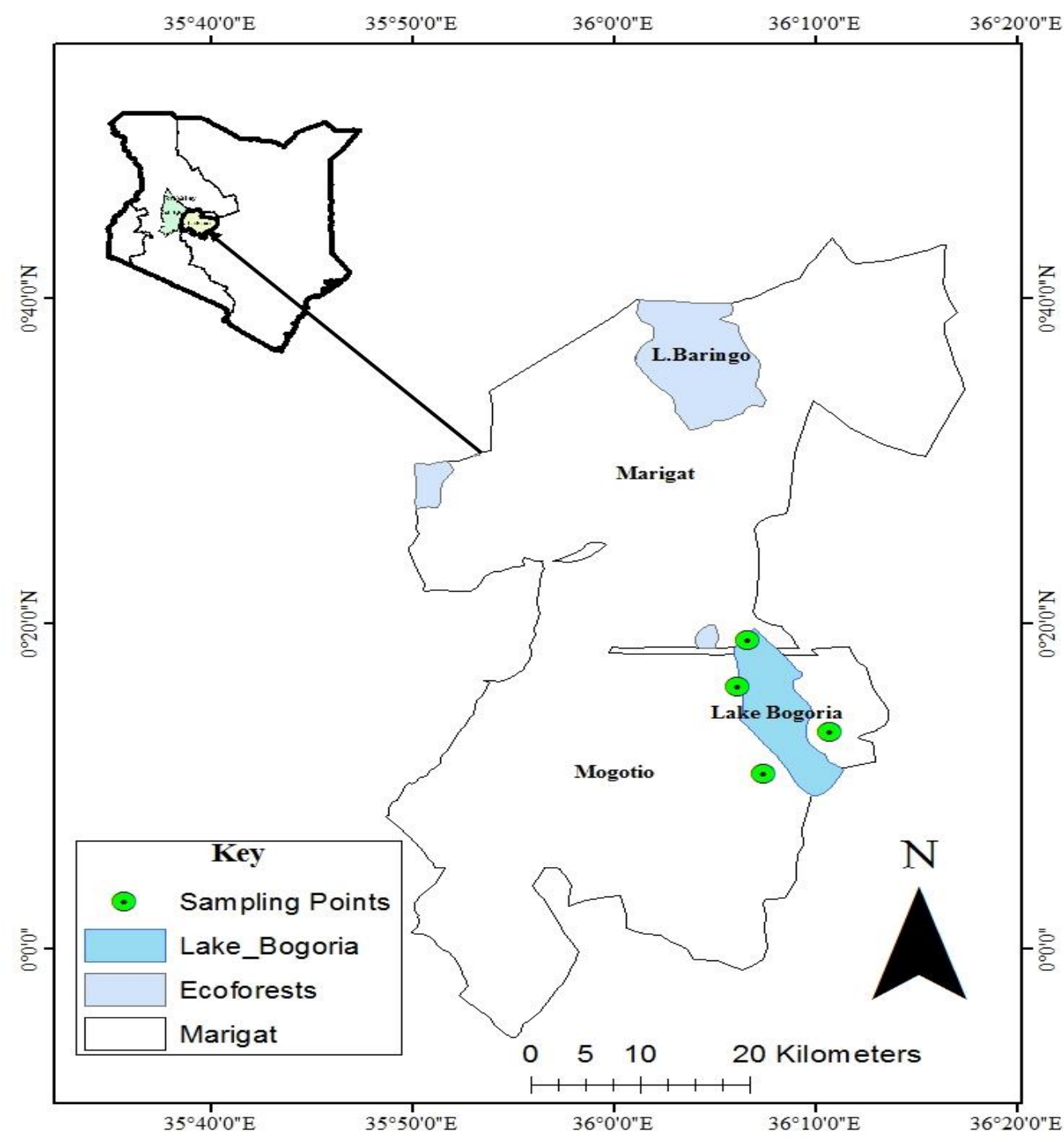

Fig. 1: Map of Study Area.

\section{Results}

The results of Experiment 1 showed out of 16 species sampled and tested only five species indicated active on impregnated picrate paper test while other eleven species had no effect on picrate paper illustrating non-cyanogenic. The species which changed color on impregnated paper include: Cynodon dactylon, Cynodon plectostachyus, Digitaria scalarum, Sporobolus spicatus and Cyperus laevigatus.

The results of age experiment show that younger cuttings of grass had relatively more concentration of cyanogenic content than older cuttings (Table 1). However in some species (C. laevigatus) older cuttings had more cyanide content than younger cuttings
(1.470 Mg CN g ${ }^{-1} \mathrm{DW}$ and $1.240 \mathrm{Mg} \mathrm{CN} \mathrm{g}^{-1} \mathrm{DW}$, respectively). There were higher levels of cyanide in C. dactylon $(1.89 \mathrm{Mg} \mathrm{CN}$ $\mathrm{g}^{-1} \mathrm{DW}$-young and $1.74 \mathrm{Mg} \mathrm{CN} \mathrm{g}^{-1} \mathrm{DW}$-old) than all other species while D. scalarum had the lowest level of cyanogenic content $\left(1.210 \mathrm{Mg} \mathrm{CN} \mathrm{g}^{-1} \mathrm{DW}\right.$ young cuttings and $1.130 \mathrm{Mg} \mathrm{CN} \mathrm{g}^{-1}$ DW older cuttings). However there were no significant difference in concentration of cyanide relative to age of grasses in all species $(\mathrm{P}>0.05)$ 
Table 1: Cyanide Levels and Age of Grasses Cyanogenic glycosides concentration $\left(\mathrm{Mg} \mathrm{CN} \mathrm{g}^{-1}\right.$ DW)

\begin{tabular}{llll}
\hline \multicolumn{4}{c}{ Cyanogenic glycosides concentration $\left(\mathrm{Mg} \mathrm{CN} \mathrm{g}^{-1}\right.$} \\
DW) & & \\
Young cuttings & Old cuttings & p-value \\
\hline C. dactylon & $1.890( \pm 0.16)$ & $1.740( \pm 0.15)$ & 0.503 \\
C. plectostachy- & $1.420( \pm 0.09)$ & $1.320( \pm 0.11)$ & 0.483 \\
us & $1.260( \pm 0.09)$ & $1.170( \pm 0.11)$ & 0.538 \\
S. spicatus & $1.240(0 \pm 0.06)$ & $1.470( \pm 0.12)$ & 0.103 \\
C. laevigatus & $1.210(0 \pm 0.08)$ & $1.130( \pm 0.07)$ & 0.447 \\
D. scalarum & & & \\
\hline
\end{tabular}

In experiment 3 the general trend shows that cyanogenic content in grasses increases with increase in grazing intensity (Fig 2-5).

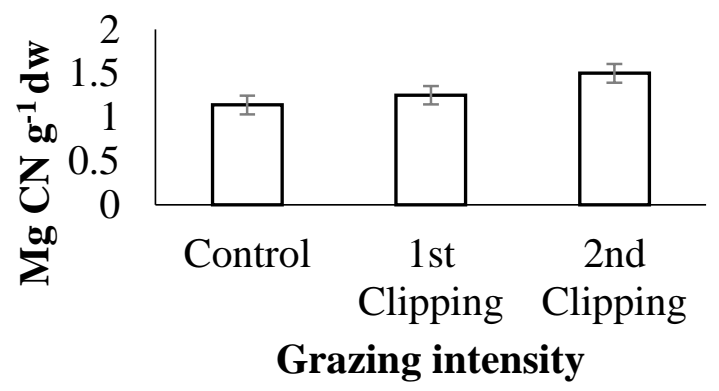

Fig. 2: Cynodondactylon.

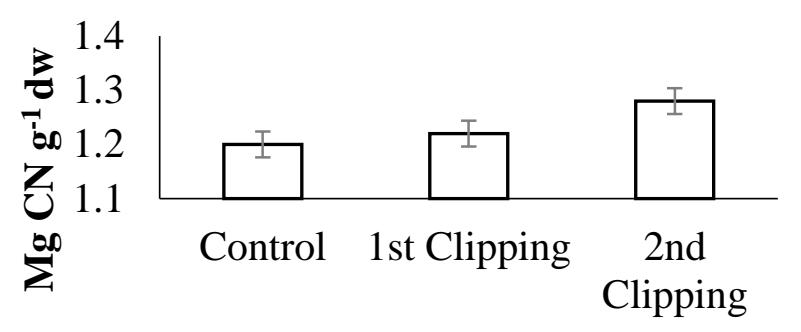
Grazing Intensity

Fig. 4: Digitariascalarum.

On basis of Tukey's comparison, null hypothesis $H_{0}: \mu_{1}=\mu_{2}=\mu_{3}=$ $\mu_{4}=\mu_{5}$ that grazing intensity has no effect on concentration of cyanide was rejected and concluded that grazing intensity influence the level of cyanogenic content in grasses. The result also showed there was no significant difference in levels of cyanide across all species except in C. laevigatus. It illustrated that C. laevigatus was most susceptible to grazing pressure as compared to other species.

Table 2: Turkey's Pairwise Comparisons of Two Grazing Intensities and Control Treatment

\begin{tabular}{|c|c|c|c|c|}
\hline Species & $\begin{array}{l}1^{\text {st }} \text { Clipping } \\
(\bar{X} 1-\bar{X} \\
2)\end{array}$ & $\begin{array}{l}2^{\text {nd }} \text { Clipping } \\
\left(\begin{array}{lll}\bar{X} & 2-\bar{X} & 3\end{array}\right)\end{array}$ & $\begin{array}{l}\text { Control } \\
\left(\begin{array}{l}\bar{X} 3-\bar{X} \\
1\end{array}\right)\end{array}$ & $\begin{array}{l}\mathrm{P}- \\
\text { value }\end{array}$ \\
\hline C. dactylon & $\begin{array}{l}0.25( \pm 0.09) \\
\text { Aa }\end{array}$ & $-0.36( \pm 0.11)_{\mathrm{Bb}}$ & $-0.11( \pm 0.064)_{\mathrm{Da}}$ & 0.024 \\
\hline $\begin{array}{l}\text { C. plectostachy- } \\
\text { us }\end{array}$ & $0.19( \pm 0.08)_{\mathrm{Aa}}$ & $-0.16( \pm 0.09)_{\mathrm{Ba}}$ & $0.03( \pm 0.052)_{\mathrm{Da}}$ & 0.202 \\
\hline S. spicatus & $\overline{0} .04( \pm 0.07)_{\mathrm{Aa}}$ & $-0.08( \pm 0.07)_{\mathrm{Ba}}$ & $-0.12( \pm 0.059)_{\mathrm{Da}}$ & 0.431 \\
\hline D. scalarum & $0.06( \pm 0.07)_{\mathrm{Aa}}$ & $-0.08( \pm 0.06)_{\mathrm{Ba}}$ & $-0.02( \pm 0.067)_{\mathrm{Da}}$ & 0.661 \\
\hline C. laevigatus & $\begin{array}{l}0.26 \\
( \pm 0.08)_{\mathrm{Aa}}\end{array}$ & $-0.31( \pm 0.06)_{\mathrm{Cb}}$ & $-0.05( \pm 0.054)_{\mathrm{Dc}}$ & 0.003 \\
\hline
\end{tabular}

\section{Discussion}

The results of the second experiment showed that generally, younger plants had a higher concentration of cyanide as compared to older. This result compares favorably with the result in the study done by Ebbs (2004, p235) which showed that cyanide concentrations in tansy were variable, but the plant appeared to concentrate cyanide where soil concentration increased. In his study,
Two sample t-test, however, showed that there was no significant difference between the two grazing intensities in all species (P>0.05). Nevertheless, one way unstacked-ANOVA test with two grazing intensity and one control experiment showed there was a significant difference in concentration of cyanide as a result of grazing intensity in two species $\mathrm{C}$. dactylon $(\mathrm{P}=0.024)$ and $\mathrm{C}$. plectostachyus $(\mathrm{P}=0.003)$ while the other three species, there was no significant difference in levels of cyanogenic glycosides under the two grazing regimes and control.

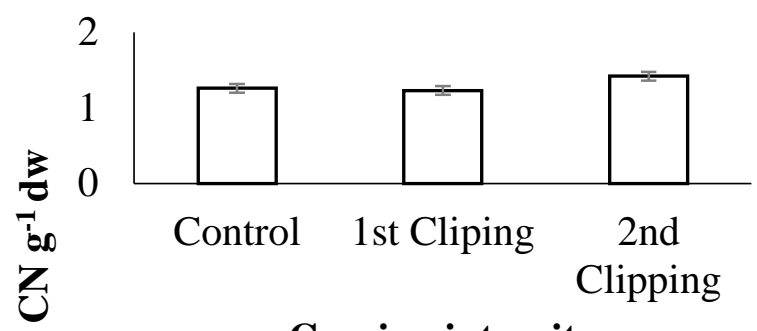

Fig. 3: Cynodonplectostachyus.

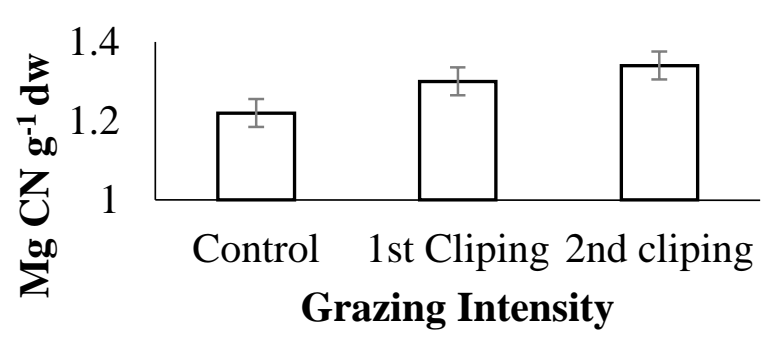

Fig. 5: Sporobolusspicatus

Ebbs concluded that the ability to concentrate cyanide may be related to plant age; i.e., younger cuttings tended to yield more $\mathrm{HCN}$ than older plants that were taken from the same cyanogenic soil. Also, the higher concentration of cyanide in younger plants has been particularly well documented in sorghum, which is highly toxic to grazing stock when young, but becomes suitable for pasture as plants mature (Ganjewala et al. 2010, p488).

According to Ballhorn (2011) CNglc concentrations are generally higher when growth is limited by environmental factors such as light, temperature, or drought. The study area classified as ASAL is generally hot and dry throughout most of the year with average annual mean temperature of about $26.6^{\circ} \mathrm{C}$ and rainfall is highly variable with annual mean of between $635 \mathrm{~mm}$. Three explanations are often presented to account for this: (a) CNglcs are concentrated in a smaller amount of plant tissue (Selmar \& Kleinwachter 2013, p819), (b) the plants are phenologically younger owing to delayed growth (Miller et al. 2014, p929), or (c) there is active upregulation at the transcriptional level (Busk \& Møller 2002, p225, Zhu-Salzman et al. 2008, p424). The magnitude of the increase in $\mathrm{HCNp}$ in response to low soil moisture depends on the severity and duration of the stress, the ontogenic stage, and the availability of other resources (Gleadow \&Woodrow 2002, p1304, O’Donnell et al. 2013, p85, Vandegeer et al. 2013, p199). In cassava, drought-stressed tubers may become more toxic because of a direct increase in concentration and relocation of linamarin from leaves to tubers. This increased HCNp in drought-stressed cassava is not permanent and decreases after plants are re-watered (Vandegeer et al. 2013, p199).

In general, plants supplied with high levels of nitrogenous fertilizers (ammonia or nitrate) have an increased content of CNglcs. 
Highly fertilized fields of forage sorghum, for example, can sometimes become toxic to livestock $(\mathrm{HCNp}>600 \mathrm{ppm}$ ) (Wheeler et al.1990, p1094, Ganjewala et al. 2010, p4). A link between nitrogen supply and CNglc deployment has also been observed in legumes, where the rate of colonization by nitrogen-fixing rhizobia has been associated with higher concentrations of linamarin and lotaustralin and decreased herbivory in both clover (Kempel et al. 2009, p635) and lima beans (Ballhorn et al. 2013, p834). Not all plants respond to nitrogen in this way. In a study by Busk \& Møller (2002) dhurrin concentration did not increase in very young seedlings grown at high levels of potassium nitrate.

In 2014 Miller et al. found out that the higher concentration of cyanide in young plants as compared to the older plants is related to enzymatic activity and adaptive mechanism. They found out that during germination and plantlet development, the cyanogenic potential of the entire seedling declines by $85 \%$ as cyanogenic compounds is metabolized to non-cyanogenic substances and negligible amounts of gaseous $\mathrm{HCN}$ are liberated during this process. However, since highest levels of the cyanide detoxifying enzyme $\beta$-cyanoalanine synthase occur in young seedling tissues, (Webber \& Woodrow 2009, p762), proposed that linamarin is transported from the endosperm via the apoplast to the young, growing tissues for further catabolism.

In further support of this, Ballhorn et al. (2008, p1299) found out that young leaves exhibit a higher $\mathrm{HCNp}$ and $\mathrm{HCNc}$ than mature leaves. They concluded that phenotypic plasticity of cyanogenesis in young leaves of lima bean Phaseolus lunatus is based on increased activity of the beta-glucosidase in response to herbivore attack. Similarly, Gleadow \& Møller (2014) found out that HCNp varies ontogenetically, phenologically, and chronologically. HCNp is generally highest in seedlings and decreases with plant age (Gleadow \& Woodrow 2000, p591, Webber \& Woodrow 2009, p765). For example, in E. cladocalyx, in the series Sejunctae, seedlings have a high HCNp (Goodger et al. 2006, p759). A similar pattern occurs in lima beans, where only secondary leaves are cyanogenic (Goodger et al. 2006, p759). Newly formed tissues are also nearly always more cyanogenic than older tissues (Gleadow \&Woodrow 2000, p599), as in E. cladocalyx, where HCNp is as high in newly formed shoots and young reproductive organs of adult plants as it is in seedlings (Gleadow \& Woodrow 2000 , p600). On the contrary, notable exceptions to the pattern described above are the cyanogenic Eucalyptus species from the series Maidenaria. They are essentially acyanogenic as seedlings $(<10$ ppm HCN), becoming cyanogenic only after 6-12 months (Goodger et al. 2006, p760).

Similarly, Webber \& Woodrow (2008) concluded that the higher $\mathrm{HCNp}$ in younger plants and plant parts is consistent with the optimal allocation theory of plant defense but as leaves expand, there may simply be a trade-off with leaf toughness and other forms of chemical defense. This may correlate with the transcript levels of the CYP79 genes involved, as in sorghum, where the CYP79A1 transcript levels are higher in young seedlings (Busk \& Møller 2002, p1224) and in L. japonicus, where expression of the two CYP genes governing the synthesis of lotaustralin and linamarin (CYP79D3 and CYP736A2) is highest in the apical leaves (Forslund et al. 2004, p75, Takos et al. 2010, 1607).

In further support of this finding, Gleadow \& Møller (2014) found out that $\mathrm{CNglc}$ concentration is usually higher in young plants, when nitrogen is in ready supply, or when growth is constrained by non-optimal growth conditions. All plants produce tiny amounts of HCN as an additional product in the biosynthesis of ethylene, but some plant species can release large amounts from endogenously stored cyanogenic glycosides (CNglcs).CNglcs may accumulate in all parts of a plant [e.g., as in cassava (Jørgensen et al. 2011, p283)], only in the aboveground parts [e.g., as in Eucalyptus (Gleadow \& Woodrow 2000, p596) and white clover (Stochmal \& Oleszek1997, p4334)], or only in vegetative $t$ issues [e.g., as in sorghum (McBee \& Miller 1980, p233)].This pattern may vary with reproductive stage as well. Some T. ulmifolia populations, for example, lose their cyanogenic capacity around flowering, whereas others do not (Schappert \& Shore 2000, p239).
The often-observed location of CNglcs and their catabolic enzymes at the periphery or other entrance sites of plant tissues (peel, epidermis, and vascular bundles) and in young, soft tissues is consistent with a defensive role.

In the third experiment, as predicted, grazing intensity influence the concentration of cyanide, the concentration of cyanide across the species tested varied considerably with some species. Two sample t-test showed that there was no significant difference in cyanogenic concentration in all the species when subjected to both grazing intensities. However, one-way ANOVA shows there was a significant difference in cyanogenic glycosides concentration of two grass species, Cynodon dactylon ( $\mathrm{p}$-value $=0.024)$ and Cyperus laevigatus $(\mathrm{P}-\mathrm{value}=0.003)$. Cyanogenic glycosides are not toxic and are stored intracellularly in the vacuole, whereas the related glycosidase is present in the cytoplasm. However, upon cell destruction by a feeding herbivore, cleaving off the aglycone moiety is no longer preventable via separation of the enzyme from the substrate. Subsequently, acetone cyanohydrin is released, which can be converted into $\mathrm{HCN}$ and acetone either spontaneously or by a hydroxynitrile lyase (Ballhorn et al. 2008, p1299)

On average the five species that shows cyanogenic trait had relatively low levels of cyanide to be considered toxic (which was highest in C. laevigatus $\left(1.580 \mathrm{Mg} \mathrm{CN} \mathrm{g}^{-1} \mathrm{DW}\right)$ and lowest in $\mathrm{D}$. scalarum $\left(1.250 \mathrm{Mg} \mathrm{CN} \mathrm{g}^{-1} \mathrm{DW}\right)$. In animals, the lethal doses of $\mathrm{HCN}$ are reported to be between 1.66 and $15 \mathrm{mg} / \mathrm{kg}$ body weight (BW) for various species (Ernesto et al. 2002, p359). These varieties, however, could be toxic to grazers if feed exclusively on particular species. In the study area, resources for grazing were limited and depleted, and grazers were considered generalize because all species of grasses were consumed and was the basis for grazers escaping poisoning. Because plants, animals, and fungi all have mechanisms to detoxify and excrete $\mathrm{HCN}$, poisoning occurs only when the rate of intake is greater than the rate of detoxification

CNglcs are only one of many defenses at a plant's disposal. Defense strategies are likely to vary with different selective pressures (magnitude and type) and with developmental stage (Agrawal 2011, p230; Ballhorn et al. 2008, p1299). CNglcs are effective deterrents to generalist herbivores (Gleadow\& Woodrow 2002, p1303, Zagrobelny et al. 2004, p1294, Ballhorn et al. 2008, p1230), and this is most likely the main evolutionary driver in their occurrence across the plant kingdom (Neilson et al. 2014 p255). CNglcs may also serve as transport forms of carbon and nitrogen (Agrawal 2011, p231), and endogenous turnover processes may release the nitrogen from $\mathrm{CNglcs}$ in the form of ammonia. More recently, it has been proposed that $\mathrm{CNglcs}$ may also function in modulating oxidative stress (Neilson et al. 2014).

In an extensive survey of the shrub T. ulmifolia, Mithöfer \& Boland (2012) found out that in naturalized populations in Jamaica, an inverse correlation was found between mean $\mathrm{HCNp}$ and the number of herbivore taxa visiting the plant (Schappert \& Shore 1999, p515). Moreover, $40 \%$ of the most highly cyanogenic individuals were not visited by insects at all. Similarly, only one insect (Leucopodoptera eumundii) has ever been found feeding on Ryparosa kurrangii (sensu R. javanica), a long-lived, highly cyanogenic understory tree from tropical Australia (Webber \& Woodrow 2008, p977).

Several studies have detected a correlation between bitterness and HCNp (Lee et al. 2013, p7755), as recognized in the common names of highly cyanogenic varieties of Prunus, such as bitter and sweet cherries (P. emarginata and P. avium, respectively) and almonds (P. amygdalus syn .P.dulcius). The level of plant defense chemicals is further influenced by damage (Kadow et al. 2012, p1254). Several specialist herbivores not only tolerate CNglcs but also actually sequester them for use in their own arsenal of defense compounds against predators (Nishida 2002, p56, Zagrobelny et al. 2007, p1190). For example, larvae of Euptoieta hegesia (Lepidoptera) that sequester CNglcs from their host (T. ulmifolia L.) are more distasteful to their Anolis predators (Zagrobelny et al. 2007, p1190; Lee et al. 2013, p7756). Larvae of the Burnet moth (Z. filipendulae; Lepidoptera) are able to sequester the CNglcs 
linamarin and lotaustralin from their cyanogenic host plants, typically bird's-foot trefoil (Zagrobelny et al. 2008, p1561, Zagrobelny \& Møller 2011, 1586).

In further support of these, Gleadow \& Møller (2014) documented evidence that demonstrates that factors affecting CNglc concentration can be explained in terms of a resource-based trade-off between plant growth and defense. The difficulty in calculating such costs may arise because the production costs are actually low and because $\mathrm{CNglcs}$ have secondarily acquired important roles in nitrogen transport and storage and offer improved tolerance to oxidative stress, offsetting the direct costs of production. They further postulates that cyanogenesis is an effective defense against generalist herbivores but is not particularly effective against fungal pathogens. Many fungi efficiently convert $\mathrm{H} \mathrm{CN}$ into ammonia and carbon dioxide. Some insect specialists have evolved mechanisms to sequester or denovo synthesize $\mathrm{CNglcs}$ and use them as their own defense against predators and as a source of reduced carbon and nitrogen (Webber \& Woodrow 2009, p763).

Nearly all of the variability in the effectiveness of cyanogenic glycosides in defense can be explained by four confounding factors. First, the concentration of the cyanogenic glycosides may be below the threshold toxicity (the concentrations are well below the capacity to cause poisoning). Second, the animal feeding on the species under examination may be a specialist that has evolved mechanisms to cope with high levels of $\mathrm{HCN}$ in the diet. Third, the cyanogenic plant might be consumed as part of a mixed diet and, therefore, might not be toxic. Fourth, the mode of feeding may be such that the animal does minimal damage to the leaf, thereby limiting the mixing of the cyanogenic glycoside with the degradative $\beta$-glucosidases and water.

\section{Conclusion}

The level of Cyanogenic glycosides varies phenologically, ontogenetically and chronologically. Generally, cyanogenic content decrease with age of plants as influenced by increased activity of the beta-glucosidase; as cyanogenic compounds is metabolized to non-cyanogenic substances as the plant matures. Moreover, the highest levels of the cyanide detoxifying enzyme $\beta$-cyanoalanine synthase occur in young seedling tissues a response to higher levels of cyanogenic content. Based on these findings, it is recommended that managed pastures ought to be utilized preferably at mature stages with low levels of cyanogenic content. On the subject of grazing pressure, plants respond to herbivory by increasing the defensive chemicals; a proxy of susceptibility to browsing. Defense strategies are likely to vary with different selective pressures (magnitude and type) and with developmental stage and grazing regimes should consider intensities as well as grazing frequency.

\section{Acknowledgement}

This research was funded by Egerton University, Division of research under Dry Land grant

\section{References}

[1] Agrawal AA (2011). New synthesis - trade-offs in chemical ecology. Journal of chemical ecology, 37(3), 230-231. http://dx.doi.org/10.1007/s10886-011-9930-7.

[2] Ballhorn DJ. (2011) Constraints of simultaneous resistance to a fungal pathogen and an insect herbivore in Lima bean (Phaseolus lunatus L.) Journal of Chemical Ecology 37:141-44 http://dx.doi.org/10.1007/s10886-010-9905-0.

[3] Ballhorn DJ, Kautz S \& Lieberei R (2010) Comparing responses of generalist and specialist herbivores to various cyanogenic plant features. Entomologia Experimentalis et Applicata, 134(3), 245-259. http://dx.doi.org/10.1111/j.1570-7458.2009.00961.x.

[4] Ballhorn DJ, Kautz S, \& Schadler M (2013) Induced plant defense via volatile production is dependent on rhizobial symbiosis. Oecologia 172:833-46 http://dx.doi.org/10.1007/s00442-012-2539-x.
[5] Ballhorn DJ, Schiwy S, Jensen M, Heil M (2008) Quantitative variability of direct chemical defense in primary and secondary leaves of lima bean (Phaseolus lunatus) and consequences for a natural herbivore. Journal Chemical Ecology 34:1298-30 http://dx.doi.org/10.1007/s10886-008-9540-1.

[6] Busk, PK, Møller BL (2002) Dhurrin synthesis in sorghum is regulated at the transcriptional level and induced by nitrogen fertilization in older plants. Plant Physiology 129:1222-31 http://dx.doi.org/10.1104/pp.000687.

[7] Ebbs (2004) Biological degradation of cyanide compounds. Journal of Biotechnology, $\quad 15, \quad 231-236$ http://dx.doi.org/10.1016/j.copbio.2004.03.006.

[8] Ernesto M, Cardoso AP, Nicala D, Mirione E, Massaza F, Cliff J, Haque MR \& Bradbury JH (2002) Persistent konzo and cyanogens toxicity from cassava in northern Mozambique. Acta Tropica 82, 357-362. http://dx.doi.org/10.1016/S0001-706X(02)00042-6.

[9] Forslund K, Morant M, Jørgensen B, Olsen, CE, Asamizu E (2004) Biosynthesis of the nitrile glucosides rhodiocyanoside $\mathrm{A}$ and $\mathrm{D}$ and the cyanogenic glucosides lotaustralin and linamarin in Lotus ja$\begin{array}{llll}\text { ponicus. } & \text { Plant } & \text { Physiology. } & \text { 135:71-84 }\end{array}$ http://dx.doi.org/10.1104/pp.103.038059.

[10] Ganjewala, D, Kumar S, Devi SA, \& Ambika K (2010) Advances in cyanogenic glycosides biosynthesis and analyses in plants: A review. Acta Biologica Szegediensis, 54(1), 1-14.

[11] Gleadow RM \& Woodrow IE (2000) Temporal and spatial variation in cyanogenic glycosides in Eucalyptus cladocalyx. Tree Physiology 20:591-98 http://dx.doi.org/10.1093/treephys/20.9.591.

[12] Gleadow RM, Woodrow IE (2002) Constraints on effectiveness of cyanogenic glycosides in herbivore defense. Journal of Chemical Ecology 28:1301-13 http://dx.doi.org/10.1023/A:1016298100201.

[13] Goodger JD, Gleadow RM \& Woodrow IE (2006) Growth cost and ontogenetic expression patterns of defense in cyanogenic Eucalyptus spp. Trees science 20:757-65 http://dx.doi.org/10.1007/s00468006-0090-2.

[14] Jørgensen K, Morant AV, Morant M, Jensen NB, Olsen CE (2011). Biosynthesis of the cyanogenic glucosides linamarin and lotaustralin in cassava: isolation, biochemical characterization, and expression pattern of CYP71E7, the oxime-metabolizing cytochrome P450 enzyme. Plant Physiology 155:282-92 http://dx.doi.org/10.1104/pp.110.164053.

[15] Kadow D, Voß K, Selmar D, Lieberei R (2012) the cyanogenic syndrome in rubber tree Hevea brasiliensis: tissue-damagedependent activation of linamarase and hydroxynitrile lyase accelerates hydrogen cyanide release. Annual Botany Reviews 109:125362 http://dx.doi.org/10.1093/aob/mcs057.

[16] Kempel A Brandl R \& Schadler M (2009) Symbiotic soil microorganisms as players in aboveground plant-herbivore interactions: the role of rhizobia. Oikos 118:634-40 http://dx.doi.org/10.1111/j.1600-0706.2009.17418.x.

[17] Lee J, Zhang G, Wood E, Castillo CR \& Mitchell AE (2013) Quantification of amygdalin in non-bitter, Semi-bitter, and bitter almonds (Prunus dulcis) by UHPLC-(ESI) QQMS/MS. Journal of Agriculture and Food Chemical 61:7754-59 http://dx.doi.org/10.1021/jf402295u.

[18] McBee GG, Miller FR (1980) Hydrocyanid acid potential in several sorghum breeding lines as affected by nitrogen fertilization and variable harvests. Crop Science. 20:232-35 http://dx.doi.org/10.2135/cropsci1980.0011183X002000020020x.

[19] Miller RE, Gleadow RM, Cavagnaro, TR (2014) Age versus stage: Does ontogeny modify the effect of phosphorus and arbuscular mycorrhizas on above- and below-ground defense in forage sorghum? Plant Cell Environment 37:929-42 http://dx.doi.org/10.1111/pce.12209.

[20] Mithöfer A \& Boland W (2012) Plant defense against herbivores: chemical aspects. Annual review of plant biology, 63, 431-450. http://dx.doi.org/10.1146/annurev-arplant-042110-103854.

[21] Møller BL (2010) Functional diversifications of cyanogenic glucosides. Current opinion in plant biology, 13(3), 337-346 http://dx.doi.org/10.1016/j.pbi.2010.01.009.

[22] Neilson EH, Goodger JQ, Woodrow IE \& Møller BL (2013) Plant chemical defense: at what cost? Trends Plant Sci. 18:250-58 http://dx.doi.org/10.1016/j.tplants.2013.01.001.

[23] Nishida R (2002) Sequestration of defensive substances from plants by Lepidoptera. Annual Reviews. Entomology 47:57-92 http://dx.doi.org/10.1146/annurev.ento.47.091201.145121.

[24] O'Donnell NH, Møller BL, Neale AD, Hamill JD, Blomstedt CK, Gleadow RM (2013) Effects of PEG-induced osmotic stress on growth and dhurrin levels of forage sorghum. Journal of Plant Physiology http://dx.doi.org/10.1016/j.plaphy.2013.09.001. 
[25] Pentzold S, Zagrobelny M, Roelsgaard PS, Møller BL, \& Bak S (2014) The multiple strategies of an insect herbivore to overcome plant cyanogenic glucoside defence. Journal of Ecology, 9(3), 91337. http://dx.doi.org/10.1371/journal.pone.0091337.

[26] Ramirez CA, \& Barry TN (2005) Alternative temperate forages are containing secondary compounds for improving sustainable productivity in grazing ruminants. Animal Feed Science and Technology, $120(3)$,

179-201. http://dx.doi.org/10.1016/j.anifeedsci.2005.01.015.

[27] Schappert PJ, Shore JS (1999) Cyanogenesis, herbivory and plant defense in Turnera ulmifolia on Jamaica. Journal of Ecoscience 6:511-20

[28] Schappert PJ \& Shore JS (2000) Cyanogenesis in Turnera ulmifolia L. (Turneraceae): Developmental expression, heritability and cost of cyanogenesis. Evolutionary Ecological Resources 2:337-52

[29] Selmar D \& Kleinwachter M (2013) Stress enhances the synthesis of secondary plant products: the impact of stress-related overreduction on the accumulation of natural products. Plant Cell Physiology 54:817-26 http://dx.doi.org/10.1093/pcp/pct054.

[30] Sirikantaramas S, Yamazaki, M, \& Saito, K (2008) Mechanisms of resistance to self-produced toxic secondary metabolites in plants.

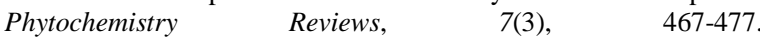
http://dx.doi.org/10.1007/s11101-007-9080-2.

[31] Stochmal A, Oleszek W (1997) Changes of cyanogenic glucosides in white clover (Trifolium repens L.) during the growing season. Journal of Agriculture 45:4333-36

[32] Takos AM, Lai D, Mikkelsen L, Maher AH \& Shelton, D, (2010). Genetic screening identifies cyanogenesis-deficient mutants of $\mathrm{Lo}$ tus japonicus and reveals enzymatic specificity in hydroxynitrile glucoside metabolism Plant Cell 22:1605-19 http://dx.doi.org/10.1105/tpc.109.073502.

[33] Ubalua AO (2010) Cyanogenic Glycosides and the fate of cyanide in Australian Journal of Crop Science, 4(4), 223-237 University of Chicago Press

[34] Vandegeer R, Miller RE, Bain M, Gleadow RM \& Cavagnaro TR (2013) Drought adversely affects tuber development and nutritional quality of the staple crop cassava (Manihot esculenta Crantz). Plant Biology 40:195-200 http://dx.doi.org/10.1071/fp12179.

[35] Webber BL \& Woodrow IE (2009) Chemical and physical plan defense across multiple ontogenetic stages in a tropical rain forest under storey tree Journal of Ecology 97:761-71 http://dx.doi.org/10.1111/j.1365-2745.2009.01512.x.

[36] Wheeler JL, Mulcahy C, Walcott JJ, \& Rapp GG (1990) Factors affecting the hydrogen cyanide potential of forage sorghum. Aust. Journal of Agricultural Resources 41:1093-100 http://dx.doi.org/10.1071/AR9901093.

[37] Woodrow IE, Slocum DJ \& Gleadow RM (2002) Influence of water stress on cyanogenic capacity in Eucalyptus cladocalyx. Functional Plant Biology, 29(1), 103-110 http://dx.doi.org/10.1071/PP01116.

[38] Zagrobelny M, Bak S, Rasmussen AV, Jorgensen B, Naumann CM \& Møller BL (2004) Cyanogenic glucosides and plant-insect interactions. Phytochemistry 65:293-306 http://dx.doi.org/10.1016/j.phytochem.2003.10.016

[39] Zagrobelny M, Bak S, Olsen CE, Møller BL (2007) Intimate roles for cyanogenic glucosides in the life cycle of Zygaena filipendulae (Lepidoptera, Zygaenidae). Journal of Molecular Biology 37:118997 http://dx.doi.org/10.1016/j.ibmb.2007.07.008.

[40] Zagrobelny M \& Møller BL (2011) Cyanogenic glucosides in the biological warfare between plants and insects: the Burnet mothbirdsfoot trefoil model system. Phytochemistry 72:1585-92 http://dx.doi.org/10.1016/j.phytochem.2011.02.023.

[41] Zagrobelny M, Bak S \& Møller BL (2008) Cyanogenesis in plants and arthropods. Phytochemistry, 69(7), 1457-1468. http://dx.doi.org/10.1016/j.phytochem.2008.02.019.

[42] Zhu-Salzman K, Salzman RA, Ahn JE, Koiwa H (2004) Transcriptional regulation of sorghum defense determinants against a phloem-feeding aphid. Plant Physiology. 134:420-31. http://dx.doi.org/10.1104/pp.103.028324. 